\title{
Leadership Style Analysis In Improving Employee Performance At University
}

\author{
Supatmin $^{1}$, Hartatik $^{2 *}$, Eni Erwantiningsih ${ }^{3}$, Ahmad Mukhlis $^{4}$ \\ ${ }^{1}$ Pamulang University, Indonesia \\ ${ }^{2}$ Sebelas Maret Surakarta University, Indonesia \\ ${ }^{3}$ Merdeka Pasuruan University, Indonesia \\ ${ }^{4}$ Bina Bangsa University, Indonesia \\ ${ }^{*}$ Corresponding author: \\ Email: Hartatik.uns@gmail.com
}

\begin{abstract}
The development of world life, in general, encourages people to move towards the era of globalization which increasingly demands an increase in the standard of order in various ways. This research is a descriptive study, with a qualitative approach, the data used are primary and secondary data, with interview, observation, and documentation data collection techniques, while the data analysis method uses descriptive analysis, because in this study the author describes the leadership style and employee performance at College.The results of the study indicate that the leadership style in the economics faculty at a university is a selling leadership style because in the economics faculty the task is very high and the relationship is also very high and the leadership always provides direction and explains the results of decisions. And also the leadership style at the Faculty of Economics because his leadership puts forward good relationships and high examples and very maximum and optimal tasks.Employee performance can be said to qualify as a good employee because the employee has been conducting in the accordance job description of each and they also work following the standards of quality, quantity, and time standards set by the faculty. However, in terms of working time discipline, more serious attention must still be needed. This can be seen in the data obtained by researchers.
\end{abstract}

Keywords: Leadership Style, Performance

\section{INTRODUCTION}

The development of world life, in general, encourages people to move towards the era of globalization which increasingly demands an increase in the standard of order in various ways. In this case, humans who are the initiators and also as resources, are expected to be able to increase competitiveness both in broad interactions, especially within the scope of an organization where humans are self-actualizing.If in an organization, humans as one of the resources that must play an active role in synergy and interact in the relationships that have been prepared and made for the creation of a commitment. The organization is a dynamic system that seeks to achieve the goals that have been planned.Organizations like today are more required to have a competitive advantage both in terms of product quality, service, cost, and professional human resources. To achieve this, human resources play a very important role and need to receive deeper attention and study, because after all, humans are the ones who ultimately determine and predict the success or failure of a policy.As one of the elements that determine the success of an organization, humans are also creatures who have certain thoughts, feelings, needs, and expectations. It needs special attention because these factors will affect achievement, dedication, and loyalty as well as love for work and organization (Hasibuan,2005:132).

Human resources are the main supporters of the organization in achieving its goals because basically, humans have skills, intelligence, willingness, hope, knowledge, trust, loyalty, and so on. All of these are characteristics possessed by humans. If these human characteristics are applied in an organization, it will manifest a form of individual behavior in an organization.Achieving the goals of an organization, also required a hierarchy structure of work as a means to clarify the division of tasks and job settings description. The existence of an element of leadership and employees is an important element of the organization is organization that has a role in carrying out operations and strategic plans. If these functions cannot run as expected, it can affect the smooth running of organizational activities within a company. Leaders and 
employees jointly carry out responsibilities and are required to have an attitude of loyalty, sincerity, skill, accuracy, passion for work, and cohesiveness in carrying out their duties. In other words, having high performance does not easily give up when faced with difficulties in carrying out the work assigned to him. Furthermore, the existence of a leader is expected to have power and authority in governing subordinates to achieve the goals that have been set. As a dominant element in decision-making, it is only natural that a leader is required to have more skills and intelligence than his subordinates.

MintzBerg (1992:20) argues that one of the determinants of a company's success in achieving the desired goals is that the company has superior human resource capabilities. In this case, they can carry out their duties and obligations following their authorities and responsibilities. The ability of a leader is needed to manage the existing human resources in the company effectively and efficiently. In general, leaders and managers do several jobs very diligently. The success or failure of an organization is largely determined by the quality of leadership that is owned by people who are given the task of leading the organization (Siagian, 2014:28). It was further emphasized that what is meant by the ability to lead by Siagian is the ability to motivate, influence, direct, and communicate with his subordinates. Even a leader must have a style or behavior and traits that are adapted to the situation and the organization to be flexible in the sense of adjusting or adapting to the maturity of his subordinates and the work environment.The ability to guide, direct, motivate, and influence is expected to improve employee performance. High performance, will ultimately encourage the company's ability to compete in the business world. In this case, the role of a leader is needed, because, with the role of a leader, the company can support the smoothness and achievement of the planned goals.

Employee performance is a combination of abilities, efforts, and opportunities that can be measured from the resulting results, therefore performance is not only about the personal characteristics shown by someone but the results of work that has been and will be done by someone. According to Darma, external things that always affect employee performance include leadership style, dependence, superior-subordinate relationships, built culture, abilities, and knowledge possessed, as well as the applied work appraisal system (2004: 135).The leadership style of a leader is leading an organization or company is very important to support the performance of employees in the company. With the existence of an effective leadership style, it is expected to increase employee performance which results in the achievement of maximum vision and mission. The Faculty of Economics is a work unit or part of an organization within the scope of the university which has many units specializing in the administration of tasks and authorities. In this unit, there is also a leader element called the dean. The role of a dean is similar to the role of a manager or other leader but differs only in the level of the area he leads. The image and culture that has been built up in the minds of government employees are that government employees are more relaxed and comfortable at work. Then automatically their performance is practically unreliable. The above, according to Robbins, is referred to as resistance to change or resistance to change which is an attitude that appears in the process of organizational change both from individuals and groups who oppose or reject the change (2003: 632).

By looking at the background of the above research issues and as well as the importance of leadership style in organizations, the authors researched with the title

" leadership style analysis in improving employee performance at university".

Based on the background above, the formulation of the problem can be taken at the economics faculty in a university, namely:

1. How is the leadership style applied at the Faculty of Economics?

2. How is the performance of employees (staff) at the Faculty of Economics?

\section{Leadership}

Leadership is a very important factor in determining the direction and goals of the organization to be achieved. In general, leadership is defined as a process of influencing the activities of individuals for groups in achieving certain goals. This understanding has been put forward by Robbins (2003:354) who says that leadership is the ability to influence a group towards the achievement (goals). This opinion views all members of a group or organization as a unit, so that leadership is given the meaning as the ability to 
influence all members of a group or organization to be willing to carry out activities or work to achieve common goals, the next understanding put forward by Owwens (1995:132) says that leadership is an interaction between a party who leads and the party being led. This opinion also states that leadership is a dynamic process carried out through a reciprocal relationship between the leader and the led. The relationship lasts and develops in achieving goals. In other words, leadership is an interpersonal relationship and a shared desire.

\section{Leadership Style}

Leadership style is defined as the behavior or method chosen and used by the leader in influencing the thoughts, feelings, attitudes and behavior of his subordinates. Leadership style can be interpreted as a leader's behavior in influencing his subordinates, meaning the leader's ability to say things correctly in a set of coordinated activities that are included in a certain leadership style. According to Darma (2004:37) defines that leadership style is a pattern of behavior shown by a person when he tries to influence others. On the other hand, Hersey and Blanchard (1992:63) argue that the most effective leadership behavior or style varies according to the maturity of the subordinates. Maturity or maturity is not in terms of age or emotional stability, but rather a desire for achievement. Awareness of responsibility and task-related abilities and experience.

The theory of leadership with a situational approach, which is an approach to leadership which states that leaders understand the behavior, characteristics of subordinates, and situations in using a certain leadership style. This leadership approach requires leaders to have diagnostic skills in human behavior. such as the theory expressed by Hessey and Blanchard by using 4 (four) leadership styles, including:

a) Directives can be called Telling (Instructions)

b) Consultative can be called Selling (Consulting)

c) Participating can be called Participating (Participation)

d) Delegative can be called Delegating (Delegation)

Thus, situational leadership emphasizes the realization of the suitability or effectiveness of the leadership style in line with the level of development of the relevant tasks of the subordinates.

\section{Employee Performance}

Performance is the result achieved or something done in the form of products or services provided by a person or group of people. Thus, performance can be seen from two sides, namely individuals and organizations (Agus Darma,2004). In more detail, it can be explained that organizational performance is cumulative of an individual or overall staff performance, where individual performance is expected to meet organizational goals, which are colored by individual work motivation and abilities possessed in carrying out work that is a burden in the organization. Employee performance is closely related to the achievement of company goals, the faster these goals can be achieved if driven by high levels of employee performance.

\section{Employee}

Employees are workers, laborers, or employees in the company (Popular Scientific Dictionary, 1994:311). The definition of employees based on Law Number 13 of 2003 concerning Manpower is those who work or receive wages or other forms of remuneration. From this understanding, the author can conclude that an employee or labor is anyone who can do work to produce goods and or services, and receive wages to meet his needs.By referring to the understanding of performance and employees above, the writer can interpret employee performance as the loyalty of employees to the tasks they carry out. Because employees have a great responsibility in their profession and as subordinates to their leaders, they are required to have high performance so that they want to do their work to the maximum. Performance is what causes employees to continue to defend a leader even though he is in a threatened state because performance is more emotional. Performance is a quality of feeling, and feelings don't always require rational explanation. Performance is like blind support, even a kind of oath of allegiance. In certain institutions, such as the state, military, and political parties, performance is the first and foremost thing demanded.

The success of an organization in achieving its goals is often equated with its performance. Performance shows a level of work results because it has carried out an activity or business. In measuring 
performance, perhaps each field uses different benchmarks.

To measure performance can be used several approaches that are closely related to the level of development of the company and the measurement, in general, can be done in the following way:

1) Quantitative development, which can be seen from the increase in the physical dimensions of a company (for example, additional employees, increased assets, increased turnover, and others.)

2) The qualitative increase is seen from the improvement of the company's quality (for example, production process, technology quality improvement, leadership quality improvement, and so on).

A combination of qualitative and quantitative progress measurement where the use of each approach will depend on the objectives to be achieved.

\section{Employee Performance Measurement}

Rivai (2004:186), asserts that measuring the performance of employees of a company is very important for a company leader, for evaluation and future planning. At the initial stage, what is measured is the performance of the company as a whole, then the work units that support it, and in the end the performance of employees who play a role in these work units are humans, then the performance of each behavior in these work units must be assessed. Determination of measuring value systems and standards will help a company leader to measure or evaluate the performance of his employees. The four steps in the process of measuring employee performance are as follows:

1. Building a standard of performance that has been based to achieve the company's research goals.

2. Measure the actual performance that has been done

3. Comparing real performance by prescribed performance standards

4. Take the necessary action

\section{Factors Affecting Employee Performance}

The role of an employee in the company is regulated by the authority and responsibility that must be carried out according to the rules of the company where they work. The authority and responsibility delegated to each employee should be carried out properly and to the maximum extent possible by the abilities and expertise possessed to be able to improve their performance. However, this may not necessarily be done well due to other factors such as motivation and expectations. In practice, the motivation and expectations of company employees are reflected in the behavior of leaders. A company leader has different behavior from one another. The extent to which a leader can meet employee expectations and can provide positive motivation to improve their performance depends on the behavior or leadership style applied. Based on the opinion above which states that leadership style is an important factor in efforts to improve employee performance, to achieve the expected company goals.

\section{METHOD}

\section{Research Types and Approach}

The type of research used is qualitative with a descriptive approach. Descriptive research describes the state of the object of research at present based on facts and data that appear or as they are. Descriptive research according to Arikunto (2002:309) is research that is intended to collect information about the status of an existing symptom, namely the state of the symptom demands what it is at the time the research is conducted. The purpose of this descriptive research is to make a description, a systematic, actual, and accurate description of the facts, nature, and relationships between the phenomena they have. Based on the description above, it can be stated that this descriptive research seeks to describe the object of research based on facts and data and events try to connect events or research objects as well as analyze them based on concepts that have been developed previously to facilitate researchers in solving problems. In this study, researchers describe the leadership style to improve employee performance.

\section{Data source}

Sources of data are subjects from which data can be obtained (Arikunto,2002:107). In this study, the data sources were the Dean and the Administrative Staff of the Faculty of Economics at the University. And it is further said that broadly speaking, there are three types of data sources which are usually abbreviated as 
3p, namely: 1). People: where the researcher asks questions about the variables studied. 2). paper: documents, archives, guidelines for decision letters (SK), and so on, a place for research to read and learn something related to research data. 3). place: laboratory room (which contains equipment), classroom workshop, and so on where activity is associated with research.Primary data is a source of research data obtained directly from the source (not through intermediary media). Primary data were specifically collected to answer research questions. This data was obtained by conducting interviews and observations with related parties.

\section{Data collection technique}

Data collection is part of the process of testing data relating to sources and ways to obtain research data. Data collection techniques in this study are:

1. Observation is the process of recording the behavior patterns of subjects (people), objects (objects), or systematic events without any questions or communication with the individuals being studied. Researchers make direct observations in employee performance.

2. The interview is a data collection technique used by researchers to obtain oral information through conversing and face to face with people who can provide information to the researcher. Researchers conducted interviews with related parties intending to complete the data obtained through observation.

3. Documentation, in the form: invoices, journal letters, minutes of meetings, memos, or in the form of program reports.

\section{Data Analysis Techniques and Data Validity}

Data analysis is the process of arranging the order in which the data is organized into a pattern, category, and basic unit of description so that it is easier to read and interpret (Moleong,2005:112). In this study, the author uses qualitative data analysis methods that do not use statistical calculations (non-statistical tests) and are limited to percentage calculations, but by using logical thinking to describe, explain and describe in-depth and systematically about the actual situation only then concluded to obtain a solution to the problem. The stages of data analysis can be carried out in several stages including collecting data with data analysis, the results of data collection of course need to be reduced (data reduction, namely by making the results of data collection as complete as possible and sorting them into certain concept units, certain categories or certain themes.

A set of data reduction results also needs to be organized into a certain form (data display) so that a more complete figure can be seen, displaying the data is very necessary to facilitate the effort of exposure and affirmation of conclusions ( conclusion ). Furthermore, in the process of data analysis in checking the validity of the data, the researcher uses the triangulation method, the triangulation method is to check the truth of the data that has been obtained to other parties who can be trusted. The triangulation technique used is technical triangulation. The triangulation technique according to Wiersma in Sugiono (2005:126) is a technique used to test the validity of the data by checking the data to the same source with different techniques, for example, data obtained by interview and then checked by observation, documentation, or questionnaires.If the three data credibility testing techniques produce different data, the researcher conducts further discussions with the relevant data source or others, to ensure the name data is considered correct. Or maybe they're all right because the point of view is different. This method is used by researchers to determine leadership style to improve employee performance.

\section{RESULT AND DISCUSSION}

\section{Leadership Style Discussion}

This study has several findings, namely, from the research findings, it is known that the leader gives orders according to the conditions and job descriptions of each employee. However, sometimes orders are also given to certain employees. So that the order is not given to all employees. In this case, the leader provides different assignment techniques to each employee. High and low assignments are given to employees following the conditions and conditions of work in the Faculty of Economics.At the Faculty of Economics, the Leader positions the employees in a non-binding manner. In this case, the leader positions 
employees flexibly, namely as subordinates, work partners, and executors of tasks. This is done so that between one another and between subordinates and superiors no barrier is too prominent and the leadership always sets an example by Islam, for example, if the employees work overtime, the leadership also joins in overtime.In behavioral theory, the Faculty of Economics applies intelligent persuasive communication which is also following what Nawawi (2003:81) said that how to communicate, how to encourage the spirit of subordinates, how-to guide and direct, how to enforce discipline, how to control and supervise his innate work, how to lead a meeting, how to reprimand and give punishment.Controlling is also carried out by superiors on the performance results of employees. However, the Faculty of Economics applies its control management.

With this management control, employees are expected to continue to work optimally. Theoretically, conventional science, assigning tasks with the right rules and conditions that effective leadership can adapt and can delegate authority effectively by considering the abilities of subordinate members and the goals to be achieved. Leaders must be flexible in adapting their leadership style or behavior to different situations. The leader can choose possible behaviors that he can use to influence members of his organization. The choice is influenced by three mutually attractive forces consisting of leaders, subordinates, and the situation.Thus, I conclude that this has described that the leadership style in the Faculty of Economics is a selling leadership style, because in the Faculty of Economics the task is very high and the relationship is also high, and also the leader always explains decisions to subordinates and also directs subordinates. The researcher concludes, in this case, it is proven that the leadership style that exists in the economics faculty is a selling leadership style, it is proven that the quantity of services carried out at home hours always exceeds office hours and the economics faculty becomes a model for other faculties because they always complete assignments first.

\section{Employee Performance Discussion}

From the application of the applied leadership style, the current employee performance is considered to be able to cover all work and can be judged to have met the criteria. However, there are still obstacles that must be considered, especially in employee discipline. Discipline, time, and accuracy of the staff of the Faculty of Economics, based on the evidence and facts of research results, it is known that there is a discrepancy between the applicable rules and the conditions in the field. The data proves that there is a discrepancy between the specified working time of the employee and the situation in the field.

According to Agus Darma (2004:225), there should be several standards that measure the implementation of employee performance, namely:

\section{a. Quantity amount to be completed \\ b. The quality of the resulting quality \\ c. Punctuality as planned}

The quantity, quality, and timeliness of doing the tasks assigned to employees can be used as a standard reference for a leader in assessing the performance of his employees.According to the Dean, saying that the employee's performance is good under the target we want, maybe the result will be an assessment even though the employees themselves in the faculty are not optimal and are still aware that they are not perfect, but the employees do their best to fulfill the service facilities for students.Employees do according to the job description as well, and responsibility, because they sense there is an assessment and challenge for them to be able to prove that the workers are done according to their assessment and also pleased with the vote despite it being The challenge for them, is that the desire to develop administrative services is part of their responsibility and they understand what they are doing with the assessment and there is an appreciation. What they understand means that what they are doing is not following the job but also not working in a certain context. and when the work is done and some friends have not finished they help them but they also work according to the job description with a sense of responsibility

The researchers also checked from the employees, they also said that so far they had worked according to their respective job descriptions that had been set by the faculty from the start and they also said that so far they had worked according to the time, quantity, quality standards that had been determined by the faculty until the end. sometimes exceed the time (overtime) because they want to work as much as possible 
to improve the quality of the faculty in the future to be even better. they also try to serve students well, be friendly even though sometimes the service time for students has run out. The researcher also checked with students that the employees were good in terms of service and administration, the employees always carried out their duties well. The students also answered that the employees worked according to what the students needed. Performance statements can be considered as appropriate. This is based on the theory of employee performance as follows:

a. Performance is the result of work achieved by an employee accomplishes in doing the duties and responsibilities assigned to them.

b. In general, employee performance is influenced by the ability, skills, experience, and sincerity of the employee concerned.

\section{CONCLUSION}

From the results of this study obtained facts to answer the formulation of the problem in this study, namely:

1. The leadership style at the Faculty of Economics is a selling leadership style because the task is very high and the relationship is also very high and the leader always gives direction and explains the results of decisions. It is proven that the quantity of service for students when they go home always exceeds office hours and also becomes a model for other faculties because the faculty of economics is always at the forefront of completing assignments. And this leadership style is very suitable when used for staff section employees and not suitable when used for lecturers because lecturers do not have to be controlled at work and also do not have to be given direction but the lecturers already understand and understanding what to do according to the job. a description each but the relationship between the lecturer and the leadership as good as well.

2. The performance of employees at the Faculty of Economics can be said to meet the criteria as good employees because all this time employees have carried out according to their respective job descriptions and they also work according to quality, quantity, and time standards set by the faculty. However, in terms of working time discipline, more serious attention must still be needed. This can be seen in the data obtained by researchers.

\section{ACKNOWLEDGMENTS}

The author would like to thank everyone and society for their support and encouragement throughout the process until the completion of this research. It is hoped that it can be used as reading material to increase the reader's insight and views on performance, as well as a source of reference and information for the same research size as well as a comparative study in the context of studying science.

\section{REFERENCE}

[1] Arikunta, Suharsimi, 2002. Procedure A Practical Approach. Revised Edition V, Publisher PT. Rineka Cipta, Jakarta

[2] Darma, Agus, 2004. Leadership Style Yes $n$ g ef ektif For The Manaje r, PT. Sinar Baru, Bandung.

[3] Hasibuan S. P, Malay, 2005. Ma Resource Mana gement usi $n$ a, Earth Literacy, Jakarta.

[4] Heresy, Paul, Balncard, Ken, 1992. M anagement Peril a ku Organisa s i, $r$ Sumbe Reform Manu's power he, Erland, Jakarta.

[5] Henry, Mintzberg and Brian Quin James, 1992. The Strategy Pocess:Concepts And Context, Engewood Difft, NJPrintice Hall

[6] Moleong, Lexy. (2005). Qualitative Research Methodology. Bandung: PT Teenager. Rosdakarya

[7] Nawawi, Hadari, 2004, Effective Leadership, Jakarta: Gadjah Madha University. press,

[8] Owwens, Robert, 1995, Organizational Behavior In Education, Ally And Bacon, Manchester

[9] Rivai, Veithzal, 2004. Kepemim p inan And Peril a ku Organisa s i, PT. Raja Grafindo Persada, Jakarta

[10] Robins, Stephen P. 2003. Organizational Behavior. Jakarta: Hadyana Pujatmaka.

[11] Sondang P. Siagian. 2014. Human Resource Management. Jakarta: Earth Literacy

[12] Sugiyono. 2005. Understanding Qualitative Research. Bandung: CV. Alphabet 